\title{
Research on the recycled and hybrid fibre reinforced self-compacting concrete under flexure
}

\author{
Malgorzata Pająk \\ Department of Structural Engineering, Silesian University of Technology, \\ 5 Akademicka Street, 44-100 Gliwice, Poland; \\ malgorzata.pajak@polsl.pl (DD)0000-0003-2627-9372
}

Funding: This work was supported by the Higher Education and National Science Centre for funding the grant no. DEC-2017/01/X/ST8/01864.

Abstract: In the present study the steel fibres coming from the end-of-life tires were applied as a reinforcement of self-compacting concrete. The influence of the recycled fibres and their mixture with glass or polypropylene fibres (hybrid mixes) on the flexural behaviour of SCC was tested. The research revealed that the dosage of $1.5 \%$ of recycled fibres is highly effective in the SCC matrix. The values of the residual flexural tensile strengths obtained in the tests classified the R-SCC to be used as a partial replacement of the conventional reinforcement. The addition of other types of fibres to R-SCC caused the further enhancement of flexural parameters with no negative effect on the distribution of the fibres in the mix.

Keywords: recycled fibres, flexure, hybrid fibres, self-compacting concrete

\section{Introduction}

In general, short fibres are added to the brittle concrete matrix to enhance its tensile mechanical parameters and cracking resistance. The fibres improve the energy absorption capacity of the concrete under dynamic loading. Because of these advantages, fibre reinforced concrete (FRC) is applied in engineering structures, e.g. tunnels, water tanks, protective structures. A broad investigation conducted globally displays an improvement of mechanical parameters of concrete due to the application of the various types of fibres [1]-[3]. However, the research mainly focusses on manufactured fibres.

If the immense need for reduction of the people-produced waste is considered, recycled steel fibres (RSF) were investigated. Precisely, fibres from the end-of-life tires were considered in this paper. The attempts to reveal the effectiveness in improving mechanical parameters of concrete of the fibres from end-of-life tires can be found only in some research [4]-[6]. The problem is associated with their poor efficiency in comparison to the same amount of manu- 
factured fibres in improving the flexural parameters of the concrete matrix [5]. In some of the papers, it was proved that when the dosage of RSF is not higher than $60 \mathrm{~kg} / \mathrm{m}^{3}$, the efficiency of the fibres in the brittle concrete matrix is low [7], [8]. However, even in this case, the RSF had a positive effect on the cracking behaviour of concrete [8].

In this paper, a significant amount of fibres was chosen because so far, the research on the behaviour of concrete with high volume ratio of RSF has been sparse. It is believed it is impossible to apply high amounts of RSF fibres to the concrete matrix because their shape would impede the random distribution of the RSF in the matrix. Furthermore, the influence on of the other fibres on the distribution of the RSF in the concrete matrix is unknown. There is no research on the mixtures, in which the RSF were mixed with other than steel fibres, therefore in this study a blend of steel and waste fibres was tested in section 5 [5] and the flexural response of self-compacting concrete reinforced with mixes of RSF, polypropylene, and glass fibres were investigated. High dosages of all types of fibres were used to highlight their mutual impact on the parameters of the matrix.

This paper is a part of the comprehensive laboratory study on hybrid fibre reinforced self-compacting concrete under quasi-static and high strain rates conditions implemented under a grant. The results presented in the paper cover the flexural response of HFR-SCC. The behaviour of the mix under high strain rates was discussed in sections 9 and 10 [9], [10]. The designation for all the mixtures were the same in all the papers to facilitate the possible linking of data and to draw further conclusions.

The first aim was to investigate when the high-volume ratio of RSF can be applied to the concrete matrix.

\section{Experimental program}

\subsection{Composition of the mix}

The research aimed to apply the high-volume ratio of the waste fibres to the self-compacting concrete matrix. The dosage of recycled fibres (R) was equal to $118 \mathrm{~kg} / \mathrm{m}^{3}$, which corresponds to a volume ratio of $1.5 \%$. Such a large number of fibres decreased the rheological parameters of SCC. Thus, the amount of superplasticizer and water had to be increased with the reference mix. The composition of the mix was assigned with the condition that the slump flow of the plain SCC and recycled fibre reinforced SCC (R-SCC) was equal.

Table 1. Mixture composition. Source: own study

\begin{tabular}{|c|c|c|c|c|c|c|c|c|c|}
\hline \multirow[b]{2}{*}{ Mix } & \multirow{2}{*}{$\begin{array}{l}\text { Cement } \\
\text { CEM } \\
\text { I 42.5R } \\
{\left[\mathrm{kg} / \mathrm{m}^{3}\right]}\end{array}$} & \multirow{2}{*}{$\begin{array}{l}\text { Natural } \\
\text { sand } \\
(0-2 \mathrm{~mm}) \\
{\left[\mathrm{kg} / \mathrm{m}^{3}\right]}\end{array}$} & \multirow{2}{*}{$\begin{array}{l}\text { Coarse } \\
\text { aggregate } \\
(2-16 \mathrm{~mm}) \\
{\left[\mathrm{kg} / \mathrm{m}^{3}\right]}\end{array}$} & \multirow{2}{*}{$\begin{array}{l}\text { Super- } \\
\text {-plasticizer } \\
{\left[\mathrm{kg} / \mathrm{m}^{3}\right]}\end{array}$} & \multirow[b]{2}{*}{$\begin{array}{l}\text { Water } \\
{\left[\mathrm{kg} / \mathrm{m}^{3}\right]}\end{array}$} & \multicolumn{3}{|c|}{$\begin{array}{l}\text { Steel fibres (\%) by } \\
\text { volume }\end{array}$} & \multirow[b]{2}{*}{$\begin{array}{l}\mathrm{w} / \mathrm{c} \\
{[-]}\end{array}$} \\
\hline & & & & & & $\mathrm{R}$ & $\mathrm{G}$ & PP & \\
\hline $\mathrm{SCC}$ & 580 & 927 & 695 & 18.4 & 202 & - & - & - & 0.34 \\
\hline R-SCC & \multirow{3}{*}{580} & \multirow{3}{*}{927} & \multirow{3}{*}{695} & \multirow{3}{*}{20.3} & \multirow{3}{*}{223} & 1.5 & - & - & \multirow{3}{*}{0.38} \\
\hline RG-SCC & & & & & & 1.5 & 0.5 & - & \\
\hline RPP-SCC & & & & & & 1.5 & - & 0.25 & \\
\hline
\end{tabular}


Table 2. Properties of the fibres. Source: own study

\begin{tabular}{|c|c|c|c|c|c|c|c|}
\hline Type of fibre & Designation & $\begin{array}{l}\text { Length } \\
{[\mathrm{mm}]}\end{array}$ & $\begin{array}{l}\text { Diameter } \\
{[\mathrm{mm}]}\end{array}$ & $\begin{array}{l}\text { Aspect } \\
\text { ratio } \\
(\mathrm{L} / \mathrm{D})[-]\end{array}$ & $\begin{array}{l}\text { Tensile } \\
\text { strength } \\
{[\mathrm{MPa}]}\end{array}$ & $\begin{array}{l}\text { Modulus } \\
\text { of elasticity } \\
{[\mathrm{GPa}]}\end{array}$ & $\begin{array}{l}\text { Density } \\
{\left[\mathrm{kg} / \mathrm{m}^{3}\right]}\end{array}$ \\
\hline $\begin{array}{l}\text { steel cord (from } \\
\text { the end-of-life } \\
\text { tires) }\end{array}$ & $\mathrm{R}$ & $\sim 2 \div 30$ & $\sim 0.15$ & $13 \div 200$ & $\geq 2850$ & 210 & 7850 \\
\hline glass & $\mathrm{G}$ & 12 & 0.014 & - & - & - & $\sim 2500$ \\
\hline polypropylene & $\mathrm{PP}$ & 12 & 0.038 & - & - & - & 910 \\
\hline
\end{tabular}

Natural sand and coarse aggregate were sourced from locally available sources in Silesia in Poland. The pebble aggregate was used. The exact composition of the mixes is presented in Table 1 and Table 2.

Hybrid mixes were created by adding glass (G) or polypropylene (PP) fibres to R-SCC. Dosages of these two types of fibres were also assigned experimentally. The $0.5 \%$ of glass fibres and $0.25 \%$ of PP fibres were added to the R-SCC. The photos of the fibres used in the analysis are collated in Fig. 1.
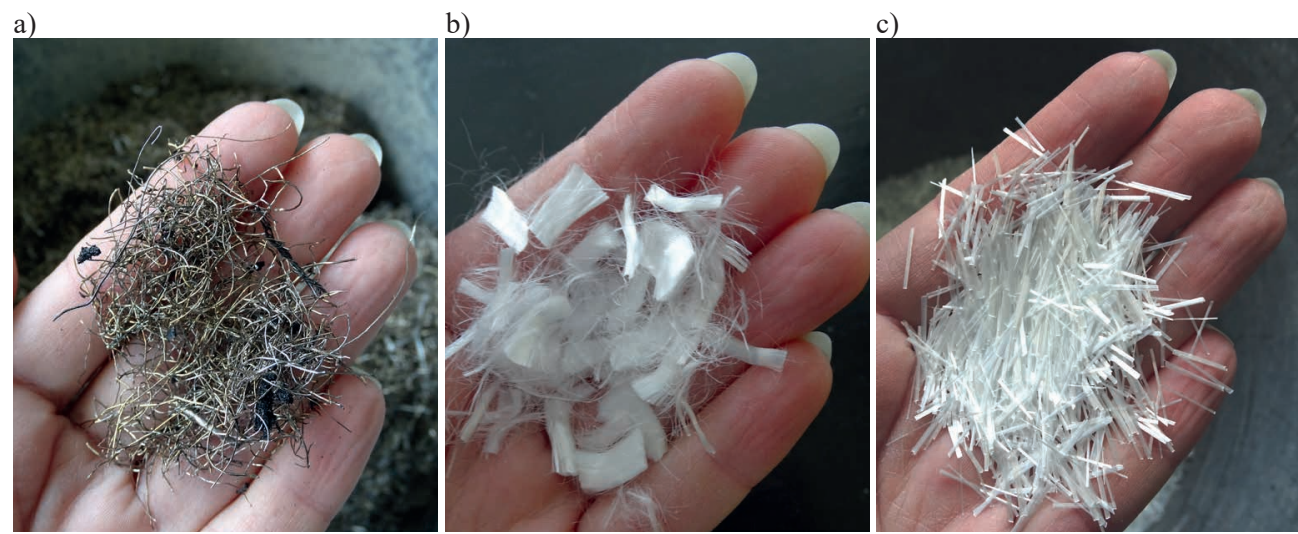

Fig. 1. View of the fibres used in the investigation: a) recycled fibres (R); b) polypropylene fibres (PP); c) glass fibres (G). Source: own study

\subsection{Flexural tests}

Flexural tensile tests were performed to investigate the improvement of the mechanical parameters of SCC after the application of fibres, with accordance with RILEM TC-162 TDF [11] and PN-EN 14651 [12]. Notched beams of the dimensions of $150 \times 150 \times 600 \mathrm{~mm}$ were subjected to the constant rate of deflection, equal to $0.2 \mathrm{~mm} / \mathrm{min}$. The CMOD was recorded during the tests. The details of the test procedure and stand can be found in other works of the author's dealings with the flexure of FRC, e.g. [13]. For each mix, three beams were tested.

\section{Results}

The results from broad research, covering the behaviour of hybrid fibre reinforced self-compacting concrete under quasi-static compression and high compression strain rates, were presented in $[9,10]$. Values of the quasi-static compressive strengths and accompanying 
strains of each mix, which were extensively discussed in previous papers, were presented in this article for the comparison (Table 3). In parenthesis, the coefficients of variation were presented.

\subsection{Rheological tests}

The slump flow of the plain SCC and R-SCC were designed to be equal. The addition of $\mathrm{G}$ or PP fibres reduced the slump flow diameter (SFD) and the time to reach $500 \mathrm{~mm}$ spread (t500) of R-SCC (Table 3). During the development of the composition of the mixture, a strong influence of the PP and G fibres on the workability of the SCC was noted. The results from slump flow tests presented in the Fig. 2 indicate that the mix of R and PP fibres disturbed the homogeneity of the mix the most. The research also covered the L-box tests, which showed that none of the mixes was able to pass through the reinforcement in the spacing equal to $30 \mathrm{~mm}$. The exact results were summarized in Table 3 .

Table 3. Rheological parameters of HFR-SCC. Source: own study

\begin{tabular}{llllll}
\hline Mix & $\begin{array}{l}\text { SFD } \\
{[\mathrm{mm}]}\end{array}$ & $\begin{array}{l}t_{500} \\
{[\mathrm{~s}]}\end{array}$ & $\begin{array}{l}\text { L-box } \\
\left(\mathrm{H}_{2} / \mathrm{H}_{1}\right) \\
{[-]}\end{array}$ & $\begin{array}{l}\text { Compressive } \\
\text { strength } \\
{[\mathrm{MPa}]}\end{array}$ & $\begin{array}{l}\text { Strain at peak stress } \\
\text { x 10-3 } \\
{[-]}\end{array}$ \\
\hline SCC & 680 & 4 & 1 & $57.7(11)$ & $0.00240(34)$ \\
\hline R-SCC & 680 & 4 & 0.52 & $53.5(2)$ & $0.00273(12)$ \\
\hline RG-SCC & 570 & 7 & 0.53 & $58.8(4)$ & $0.00300(5)$ \\
\hline RPP-SCC & 580 & 6 & 0.53 & $52.7(1)$ & $0.00284(19)$ \\
\hline
\end{tabular}
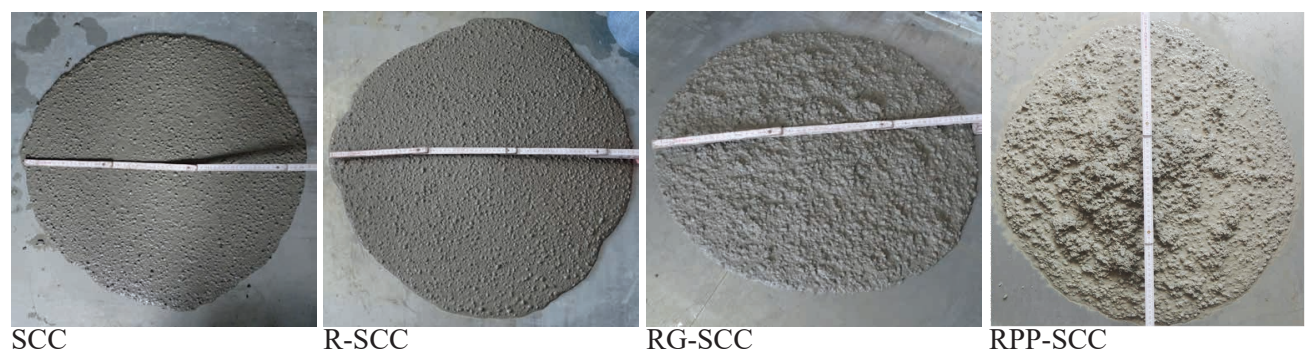

Fig. 2. Slump flow of the mixes. Source: own study

\subsection{Flexural tensile tests}

\subsection{1. $R-S C C$}

The results from flexural tests of the mixes were presented as load-CMOD curves in Fig. 3, and Fig. 4. Each graph contains the load-CMOD curves of three beams and their average. 
a)

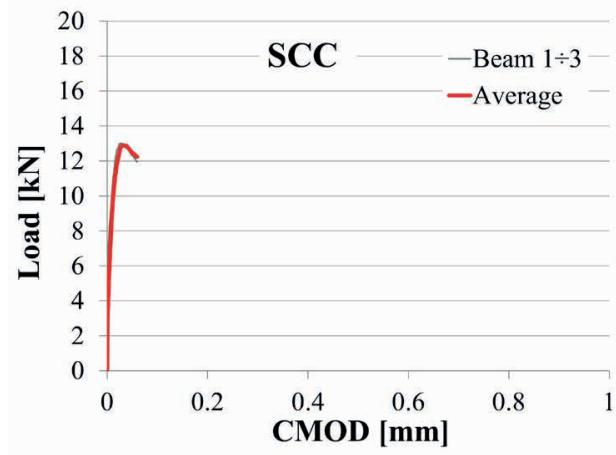

b)

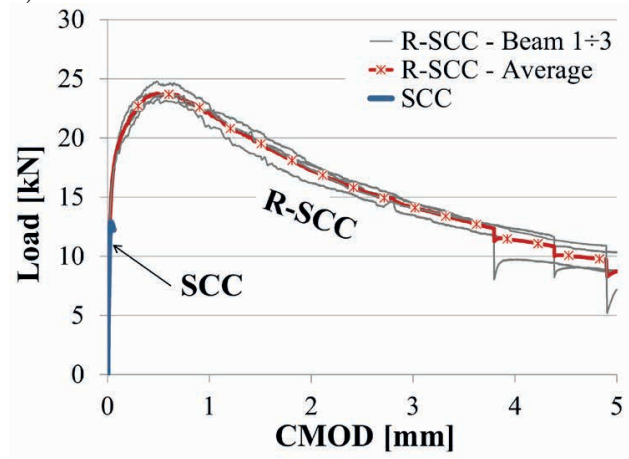

Fig. 3. Load-CMOD curves obtained in flexural tests of mixes: a) SCC, b) R-SCC. Source: own study

The application of $118 \mathrm{~kg} / \mathrm{m}^{3}$ of fibres recovered from used tires caused the pronounced enhancement of the mechanical parameters of the SCC (Fig. 3b). The maximum flexural tensile strength of plain SCC increased about twice, due to incorporation of RSF. The post-elastic mechanical parameters of SCC were significantly improved by recycled fibres, which can be seen in the comparison of the results of the tests presented in Fig. 3b. The results of the tests covering, e.g. residual and equivalent tensile strengths were presented in Table 4. The coefficients of variation were presented in parenthesis.

Table 4. Flexural tests results. Source: own study

\begin{tabular}{|c|c|c|c|c|c|c|c|c|c|c|c|c|c|}
\hline \multirow[b]{2}{*}{ Mix } & \multirow{2}{*}{$\begin{array}{l}f_{\mathrm{LOP}} \\
{[\mathrm{kN}]}\end{array}$} & \multirow{2}{*}{$\begin{array}{l}f_{\mathrm{LOP}} \\
{[\mathrm{MPa}]}\end{array}$} & \multirow{2}{*}{$\begin{array}{l}f_{\max } \\
{[\mathrm{kN}]}\end{array}$} & \multirow{2}{*}{$\begin{array}{l}\delta_{\mathrm{Fmax}} \\
{[\mathrm{mm}]}\end{array}$} & \multicolumn{2}{|c|}{$\begin{array}{l}\text { Equivalent } \\
\text { flexural tensile } \\
\text { strength } \\
{[\mathrm{MPa}]}\end{array}$} & \multicolumn{4}{|c|}{$\begin{array}{l}\text { Residual flexural } \\
\text { tensile strength } \\
{[\mathrm{MPa}]}\end{array}$} & \multirow{2}{*}{$\begin{array}{l}\text { Toughness } \\
{[\mathrm{N} / \mathrm{m}]}\end{array}$} & \multirow{2}{*}{$\begin{array}{l}f_{\mathrm{R}, 1} / f_{\mathrm{LOP}} \\
{[-]}\end{array}$} & \multirow{2}{*}{$\begin{array}{l}f_{\mathrm{R}, 3} / f_{\mathrm{R}, 1} \\
{[-]}\end{array}$} \\
\hline & & & & & $f_{\mathrm{eq}, 2}$ & $f_{\mathrm{eq}, 3}$ & $f_{\mathrm{R}, 1}$ & $f_{\mathrm{R}, 2}$ & $f_{\mathrm{R}, 3}$ & $f_{\mathrm{R}, 4}$ & & & \\
\hline $\mathrm{SCC}$ & $\begin{array}{l}12.78 \\
(2)\end{array}$ & $\begin{array}{l}4.09 \\
(2)\end{array}$ & $\begin{array}{l}12.9 \\
(1)\end{array}$ & $\begin{array}{l}0.04 \\
(40) \\
\end{array}$ & - & - & - & - & - & - & - & - & - \\
\hline $\begin{array}{l}\text { R- } \\
\text { SCC }\end{array}$ & $\begin{array}{l}16.78 \\
(2)\end{array}$ & $\begin{array}{l}5.37 \\
(3) \\
\end{array}$ & $\begin{array}{l}23.9 \\
(3)\end{array}$ & $\begin{array}{l}0.32 \\
(21) \\
\end{array}$ & $\begin{array}{l}7.34 \\
(5) \\
\end{array}$ & $\begin{array}{l}5.49 \\
(10) \\
\end{array}$ & $\begin{array}{l}7.60 \\
(3) \\
\end{array}$ & $\begin{array}{l}6.26 \\
(4) \\
\end{array}$ & $\begin{array}{l}4.97 \\
(4) \\
\end{array}$ & $\begin{array}{l}4.15 \\
(3) \\
\end{array}$ & $\begin{array}{l}61.24 \\
(3) \\
\end{array}$ & 1.4 & 0.65 \\
\hline $\begin{array}{l}\text { RG- } \\
\text { SCC }\end{array}$ & $\begin{array}{l}20.32 \\
(6)\end{array}$ & $\begin{array}{l}6.50 \\
(6) \\
\end{array}$ & $\begin{array}{l}27.6 \\
(3)\end{array}$ & $\begin{array}{l}0.60 \\
(40) \\
\end{array}$ & $\begin{array}{l}7.10 \\
(13) \\
\end{array}$ & $\begin{array}{l}6.37 \\
(9) \\
\end{array}$ & $\begin{array}{l}8.77 \\
(3)\end{array}$ & $\begin{array}{l}6.69 \\
(6)\end{array}$ & $\begin{array}{l}5.31 \\
(9) \\
\end{array}$ & $\begin{array}{l}4.33 \\
(14) \\
\end{array}$ & $\begin{array}{l}67.26 \\
(6)\end{array}$ & 1.4 & 0.61 \\
\hline $\begin{array}{l}\text { RPP } \\
-\mathrm{SCC}\end{array}$ & $\begin{array}{l}17.79 \\
(3)\end{array}$ & $\begin{array}{l}5.69 \\
(3) \\
\end{array}$ & $\begin{array}{l}28.3 \\
(9)\end{array}$ & $\begin{array}{l}0.38 \\
(26)\end{array}$ & $\begin{array}{l}8.80 \\
(6)\end{array}$ & $\begin{array}{l}6.67 \\
(9)\end{array}$ & $\begin{array}{l}8.95 \\
(8)\end{array}$ & $\begin{array}{l}7.39 \\
(8) \\
\end{array}$ & $\begin{array}{l}5.69 \\
(12) \\
\end{array}$ & $\begin{array}{l}4.62 \\
(11) \\
\end{array}$ & $\begin{array}{l}71.52 \\
(9)\end{array}$ & 1.6 & 0.64 \\
\hline
\end{tabular}

In the research, the hardening phase was observed before reaching the maximum load. This type of flexural response is usually observed in the case of long fibres with the shape that ensures a good anchorage in the concrete matrix. Even high number of straight, short fibres was not able to trigger such an effect on the flexural behaviour of SCC, which was previously investigated in [13]. Therefore, this research proves that the length together with the curved and twisted shape of the RSF provides a very good anchorage of the RSF in the SCC matrix. The fact that the type of steel used in the tires are characterized by much higher tensile strength and ductility than the steel used for the production of typical fibres should also be considered [14]. 
In the previous work of the author [7], where the dosage of RSF was in the range of $30 \div 60 \mathrm{~kg} / \mathrm{m}^{3}$, their influence on peak and post-peak parameters of concrete were rather weak. No hardening phase in the flexural response was observed in this instance. The increase of the maximum load of concrete reinforced with recycled fibres did not exceed $25 \%$ of plain concrete. The meaningful dispersion of the results with the increase of the volume ratio of the fibres was noted. In the current research, this conclusion was not confirmed. A much bigger dosage of the RSF than in [7] was analyzed. The proceedings of the load-CMOD curves were comparable in the case of all the specimens that can be seen in the Fig. 3b. Notably, in [7] the conventional concrete was exanimated, which means it needs to be vibrated, whereas, in this study, self-compacting concrete was investigated. Thus, probably, the process of vibration was responsible for the dispersion of the results in [7].

\subsubsection{Hybrid fibres}

The R-SCC mix was further improved with glass (G) and polypropylene (PP) fibres (Fig. 4). Both types of fibres (G, PP) had a comparable influence on the flexural response of the R-SCC. Their addition caused the increase of maximum load and flexural mechanical parameters of the SCC matrix already containing the recycled fibres (Fig. 4).

a)

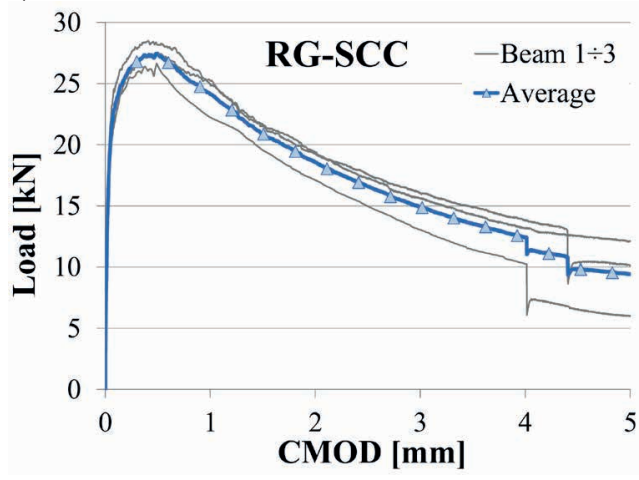

b)

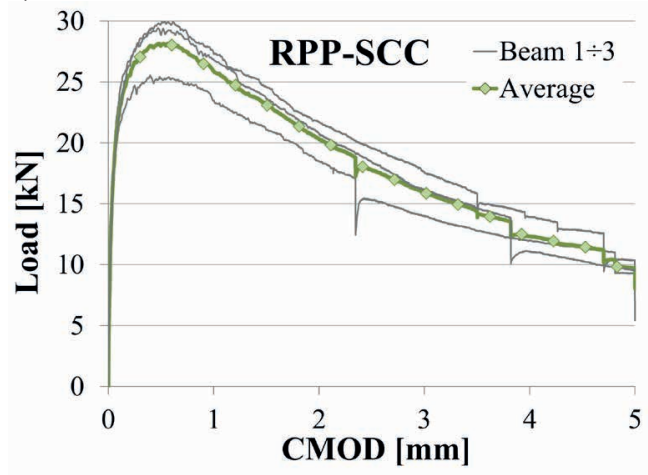

Fig. 4. Load-CMOD curves obtained in flexural tests of mixes containing hybrid fibres: a) RG-SCC; b) RPP-SCC. Source: own study

The scatters between the load-CMOD curves of mixes containing hybrid fibres were indeed more noticeable than in the case of the R-SCC (Fig. 3b). However, they still weren't meaningful. Although the dosage of polypropylene and glass fibres was high, it can be concluded that the addition of other types of fibres did not affect the distribution of the recycled fibres.

The comparison of the average load-CMOD curves obtained in all tests are presented in Fig. 5. It can be clearly seen that additional fibres (PP or G) improved the flexural parameters of the R-SCC. Polypropylene fibres seem to be more effective than the glass fibres. However, this difference was not pronounced. 


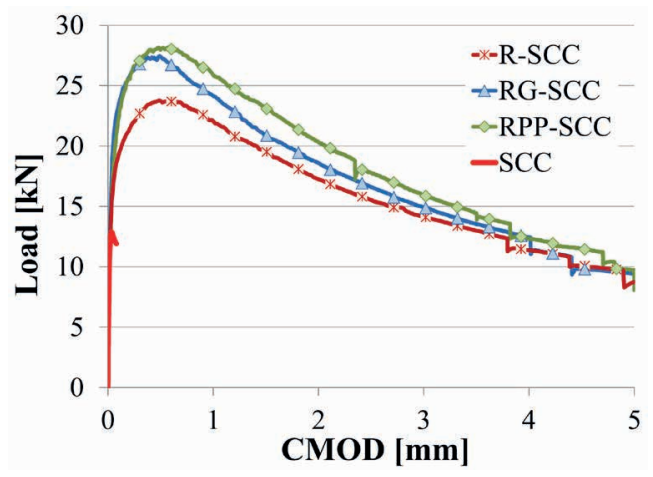

Fig. 5. Comparison of the load-CMOD curves. Source: own study

In general, the fibres bridge the cracks in the concrete matrix. Their effectiveness in the brittle matrix depends mainly on the dosage, length and material of the fibres. The shortest fibres can attract microcracks, while the longer ones delay the propagation of more significant cracks. In this paper, the PP fibres in combination with the RSF fibres were more effective in the matrix because their modulus of elasticity is lower than in the case of G fibres. The density of polypropylene fibres is lower than the glass fibres. Thus, the number of PP fibres was much higher in the matrix than in the case of $\mathrm{G}$ fibres. The difference in the impact on the load-CMOD relationship is not pronounced because the length of both types of fibres and their perimeter were somewhat comparable.

The investigations showed that the replacement of the manufactured fibres with the recycled ones is possible. The $1.5 \%$ of volume ratio of the RSF resulted in the increase of flexural parameters of the matrix. The enhancement that could be compared to the one obtained in the case of hooked fibres is believed to be the most effective in the concrete matrix. However, much smaller dosage of hooked fibres than the RSF would probably produce the same effect on the flexural parameters of the SCC.

\section{Application of recycled fibres}

There are two main applicable standards that deal with FRC: RILEM TC 162-TDF [11] and MC 2010 [15]. The procedure to obtain mechanical parameters from laboratory investigation that can be further applied in the calculation of FRC according to RILEM TC 162-TDF [11] was previously presented by the author in [7], where lower dosages of recycled fibres than in this paper were analysed. Herein, the approach proposed by MC 2010 [15] was discussed.

Considering the FRC reinforced with conventional bar reinforcement, the fibres carry the load in the tensile zone, which decreases the stress and strain in bars. MC2010 [15] classifies the FRC based on three parameters from flexural tests performed on notched beams: $f_{\mathrm{R}, 1}$, $f_{\mathrm{R}, 3}$ and $f_{\mathrm{LOP}}$. According to MC2010 [15], the fibres can be considered in Ultimate Limit State (ULS) calculations when the conditions (1) are fulfilled:

$$
\frac{f_{R, 1}}{f_{L O P}}>0.4 ; \frac{f_{R, 3}}{f_{R, 1}}>0.5
$$

In other words, the residual flexural tensile strength of FRC at the CMOD equal to $0.5 \mathrm{~mm}\left(f_{\mathrm{R}, 1}\right)$ should be higher than $40 \%$ of the flexural tensile strength at the limit of proportionality $\left(f_{\text {LOP }}\right)$. Thus, the fibres had to act in the concrete matrix after the cracking occurred. 
Furthermore, when the CMOD reaches $2.5 \mathrm{~mm}$ the FRC should still have the residual tensile strength $\left(f_{\mathrm{R}, 3}\right)$ not lower than $50 \%$ of the residual flexural tensile strength at CMOD $=0.5 \mathrm{~mm}$ $\left(f_{\mathrm{R}, 1}\right)$ and in truth $20 \%$ of $f_{\mathrm{LOP}}$.

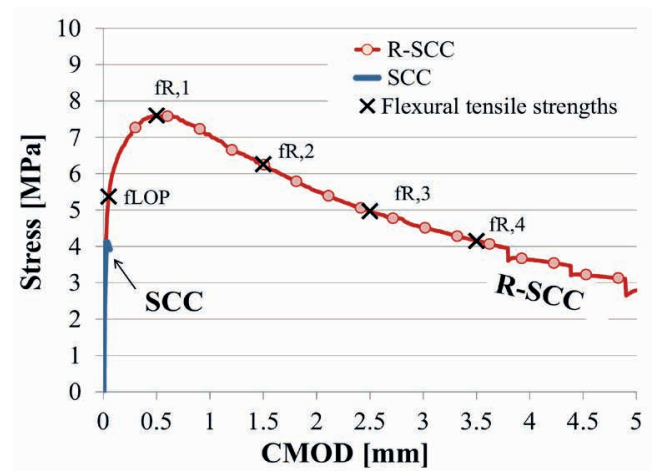

Fig. 6. The average residual flexural tensile strengths-CMOD curve for R-SCC. Source: own study

The residual flexural tensile strengths of R-SCC are depicted in Fig. 6. The R-SCC residual strength class acc. to MC 2010 [15] is "a". It can be clearly seen in Table 4 that the dosage of $1.5 \%$ of the RSF exceeds the requirements (1). Though, the RSF could be used as a partial substitute to conventional reinforcement and decrease the number of bars. However, the L-box test results indicate, that the mix with such high dosage of fibres is not able to pass through the reinforcement with a distance of $30 \mathrm{~mm}$. Therefore, it could be applied in, e.g. ground slabs, where the distance between the bars is usually much higher and can't be lower than $50 \mathrm{~mm}$.

\section{Conclusions}

Based on the investigations performed, obvious advantages for the SCC brittleness with the application of huge amount of RSF can be noted. The main conclusions are:

- The addition of $1.5 \%$ of recycled fibres to SCC resulted in pronounced enhancement of the flexural parameters of the matrix.

- Based on the collation of current results with the results from the tests previously performed, it can be concluded that the effectiveness of the RSF was much better in self-compacting concrete than in conventional concrete. Thus, probably the influence of the process of vibration on the results in much higher than it is in the case of manufactured fibres.

- Hybrid mixes containing RSF and glass or polypropylene fibres exhibit higher flexural peak and post-peak parameters than the mixes containing only RSF.

- The addition of glass and polypropylene fibres to the R-SCC did not influence the distribution of RSF in the SCC pronouncedly. The proceedings of the load-CMOD curves obtained for the mixes with hybrid fibres were comparable.

- According to the MC2010, the flexural parameters of all the mixes could be considered in the ULS calculations of the structural elements.

One of the main conclusions from the research is that the manufactured fibres could be replaced by the recycled fibres with the same effect on the flexural parameters of the self-com- 
pacting concrete matrix. Admittedly, higher volume ratio of the RSF should be applied to achieve the same effect as it is in the case of manufactured fibres, nevertheless it is possible.

\section{References}

[1] Brandt A.M., "Fibre reinforced cement-based (FRC) composites after over 40 years of development in building and civil engineering", Composite Structures, vol. 86, (2018), pp. 3-9. https:// doi.org/10.1016/j.compstruct.2008.03.006

[2] Rizzuti L., Bencardino F., "Effects of Fibre Volume Fraction on the Compressive and Flexural Experimental Behaviour of SFRC", Contemporary Engineering Sciences, vol. 7, (2014), pp. 379-390. http://dx.doi.org/10.12988/ces.2014.4218

[3] Abbass A., Abid S., "Ozakça M., "Experimental Investigation on the Effect of Steel Fibers on the Flexural Behavior and Ductility of High-Strength Concrete Hollow Beams", Advances in Civil Engineering, (2019), https://doi.org/10.1155/2019/8390345.

[4] Groli G., Caldentey A.P., Marchetto F., Fernández F.A., "Serviceability performance of FRC columns under imposed displacements: An experimental study", Engineering Structures, vol. 101, (2015), pp. 450-464.

[5] Zamanzadeh Z., Lourenço L., Barros J., "Recycled Steel Fibre Reinforced Concrete failing in bending and in shear", Construction and Building Materials, vol. 85, (2015), pp. 195-207.

[6] Centonze G., Leone M., Aiello A.M., "Steel fibers from waste tires as reinforcement in concrete: A mechanical Characterization", Construction and Building Materials, vol. 36, (2012), pp. 45-67.

[7] Pająk M., "Concrete reinforced with various amounts of steel fibres reclaimed from end-of-life tires." in 64 Scientific Conference of the Committee for Civil Engineering of the Polish Academy of Sciences and the Science Committee of the Polish Association of Civil Engineers (PZITB) (KRYNICA 2018), MATEC Web of Conferences, vol. 262, 2019.

[8] Groli G., Caldentey A.P., Soto A.G., "Cracking performance of SCC reinforced with recycled fibres - an experimental study", Structural Concrete, vol. 15, no. 2, (2014), pp. 136-153.

[9] Pająk M., Janiszewski J., Kruszka L., "Hybrid fiber reinforced self-compacting concrete under static and dynamic loadings", in Proceedings of the Symposium 2019: Concrete - Innovations in Materials, Design and Structures, 2019, pp. 766-772.

[10] Pająk M., Janiszewski J., Kruszka L., "Laboratory investigation on the influence of high compressive strain rates on the hybrid fibre reinforced self-compacting concrete", Construction and Building Materials, vol. 227, (2019). https://doi.org/10.1016/j.conbuildmat.2019.116687

[11] RILEM TC 162-TDF, “Test and design methods for steel fibre reinforced concrete. Bending tests. Final recommendations", Materials and Structures, vol. 35, (2002), pp. 579-82.

[12] PN-EN 14651, "Metody badania betonu zbrojonego włóknem stalowym. Pomiary wytrzymałości na rozciąganie przy zginaniu (granica proporcjonalności LOP)”, (2007).

[13] Pająk M., Ponikiewski T., "Flexural behavior of self-compacting concrete reinforced with different types of steel fibers", Construction and Building Materials, vol. 47, (2013), pp. 397-408. https:// doi.org/10.1016/j.conbuildmat.2013.05.072

[14] Domski J., Katzer J., Zakrzewski M., Ponikiewski T., "Comparison of the mechanical characteristics of engineered and waste steel fiber used as reinforcement for concrete", Journal of Cleaner Production, vol. 158, (2017), pp. 18-28. https://doi.org/10.1016/j.jclepro.2017.04.165

[15] Model Code 2010 - Final Draft, FIB Bulletin, vol. 1-2, (2012). 
